Christl verduyn, Associate Professor, French Section, Department of Modern I anguages and Literatures, Trent Iniversity, has published various articles in the area of comparative Québec and English Canadian women's writing.

\title{
Murder in the Dark: fiction/theory by Margaret Atwood
}

\author{
CHRISTL VERDUYN
}

MARGARET ATWOOD'S 1983 publication, Murder in the Dark, is part of a movement in English Canadian women's writing away from a pre-modernist literary tradition towards modernist and post-modernist projects in fiction. Indeed, this collection of short fictions and prose poems by Atwood can be confidently described as a "fiction théorique".

Readers will recall the steps through which the journey away from traditional fiction took place. The modernist project began by rejecting the idea of fiction as representation of reality replacing it with the representation of fiction as artifice, as language in the making/working/playing, as discourse. Modernism's self-conscious focus on the act of writing led to the post-modernist loss of faith in the realist story and to the metafictional text - fiction about fiction making - as well as to an increased emphasis on the participation of the reader in the co-creation of the text. Many of the modernist/post-modernist objectives proved compatible with feminist objectives in the area of literature and literary criticism and together their odyssey comprised three main strategies: the dismantling of language, which was exposed as another of patriarchy's institutions; the scrutinizing and exploding of both the reality patriarchal language has described and the fictions it has inscribed; the construction of a "feminine language" closely linked to the female body. This was essentially a theoretical project. Just as revolutionary science requires the development of new language and cpistemology to break away from received visions of the world in a move towards the depiction of a truer reality, so too the new writing by women involved the development of new words/language and tools/forms to illustrate a new reality. Margaret Atwood's Murder in the Dark rests comfortably within this project. In its experimentation with different fictional devices, in its self-conscious theorizing about language and forms, in its unmitigated assault on patriarchy and the reality and fictions which it has generated, and in its productive use of the body to envision a new reality and a new language - in all of these ways, Margaret Atwood moves towards the production of a theoretical fiction in Murder in the Dark. 
The first short piece of the volume, entitled "Autobiography", demonstrates in microcosm the project in which Atwood is engaged. As in subsequent texts, the form of "Autobiography" is in itself unsettling; this must be the world's shortest, not to say oddest, autobiography! In eleven point-blank and, to a certain extent, banal sentences, Atwood describes, in seemingly traditional fashion, a landscape: there is a lake, sky, a white sand cliff; a river, a dam, a covered bridge, some houses, a white church; a rock island, a few trees, boulders, a path, a forest, horses, birds and so on -in all, a fairly boring reality. However: "The first thing I can remember is a blue line." 1 The essence of the reality is not the representation ${ }^{2}$ of a tree or a forest or whatever, but a line - a seam - "where the lake disappeared into the sky" (9) - the "I" of "Autobiography" standing with her eyes on the horizon. It is in this seam and in the I/eye that reality is exploded: "Once, on the rock island, there was the half-eaten carcass of a deer which smelled like iron, like rust rubbed into your hands so that it mixes with sweat"'(9). What does this have to do with the flat reality just described? The scene is unsettled, the reader is jolted, the purpose of this autobiographical journey is suddenly uncertain. Indeed, in this sense, the landscape is destroyed as a self-indulgent recollection of an ordinary scene is exploded into something far more interesting: "This smell is the point at which the landscape dissolves... becomes something else" $(9)$. This something else - this new reality - emerges out of a landscape which has been undone and in which bodily function - in this instance, the sense of smell (the smell of the halfeaten deer) - simultaneously unsettles and creates.

The structural form of "Autobiography" - "reality" being destroyed or deconstructed and simultaneously recreated via fiction or writing - here, the autobiography - into a new reality - is one used throughout Murder in the Dark. Each text presents a seeming reality - in most cases a rather mundane, traditional reality, and in some cases an obviously patriarchal one - in which, through a given device, banal and/or oppressive reality is exploded or deconstructer and in the process there emerges, in dialectic, or more precisely spiral fashion, the creation of a new potential and immediacy, a new reality. This strategy is most easily depicted in the title piece of the volume.

1. This and subsequent quotes are from Margaret Atwood, Murder in the Dark, (Toronto: Coach House Press, 1983), p. 9.

2. Emphasis mine. With two exceptions to be noted further ahead, italics throughout the text indicate my emphasis. 
Whether played by adolescents or by adults, the game called Murder in the Dark, is played in the darkness. The lights are turned out, everyone gropes about in the dark, and eyes are useless. The game is first played as a diversion, in which adolescents have the chance to excite one another in the dark. 'This self-indulgent game/reality is upset, however, in the more adult version of the game. Pieces of paper are folded and put into a hat and people choose their roles by drawing these pieces of paper. A detective is chosen and a murderer. The detective leaves the room, turning off the lights, and in the dark the murderer chooses a victim. The detective returns and attempts to discern who is the killer. Playing the game with adults, "six normal people and a poet"(29), the latter, in a significant confusion of fiction and reality, really tries to kill someone. Indeed, $\mathrm{s} / \mathrm{he}$ is prevented from doing so only by the intervention of a dog "which could not tell fantasy from reality"'(29).

What exactly is going on here?

...you can play games with this game. You can say: the murderer is the writer, the detective is the reader, the victim is the book. Or perhaps, the murderer is the writer, the detective is the critic and the victim is the reader. In that case the book would be the total mise en scene ... But really it's more fun just to play the game... Just remember this, when the scream at last has ended and you've turned on the lights: by the rules of the game, I must always lie.

Now do you believe me?(30)

The analogous relationship between the game and writing is established: the murderer/liar/writer destroys - literally murders - reality in order to construct a new reality via fiction or writing or language. This murdering is neither work nor imposition - it's fun! It involves both the writer/murderer and the reader/detective in a joint project. But it is an unsettling one, the reader/detective being confronted with a murdered/liar/writer and the entire project unfolding in the dark...

In the challenge of deconstructing "reality" and recreating it through fiction, depictions of everyday reality - children playing games ("Making Poison"), nostalgic visits to grandparents' treasure-filled attics ("The Boys' Own Annual, 1911), friends going to the store to buy popsicles ("Horror Comics"), making clothes to wear on dates ("Boyfriends") - all of these common, everyday events are presented in flat, predictable ways until the writer/liar/murderer unsettles the scene, deconstructs the reality, writing/ creating a new one. Hence, childhood play involves making poison; in nostalgic trips to the attic, stories about strange creatures and mad and sinister people are read; comic books transform friends into vampires; boy- 
friends dissolve into damp and smelly blurred shapes; and aging stripteasers are exposed and humiliated. Undone by the writer/liar/murderer, these realities lead to a different sort of scene, a different sort of reality. Making poison becomes as much fun as making a cake - and "[i]f" you don't understand this you will never understand anything"(10). The absent last volume of the "Boys' Own Annual" allows the writer/murderer/liar to invent the last story, in which a grandmother stalks an invisible person, possibly an uncle gassed in the first war and never right since, the former owner of the Boys' Own Annual(11). Horror comics allow the illustration of a reality which includes hatred - "pure hatred"?(13) Boyfriends dissolve into texture(14) and an aging stripteaser's mask of a face and purple mouth become a mockery, "a trick of another kind"(15). The first part of Murder in the Dark ends with a story called "Fainting", in which first an ordinary school outing and then a walk on the dock become confrontations with embryos and flesh, and a fainting spell allows the writer/murderer/ liar to get a new view - a view from her feet - "looking up at a forest of canvas overshoes and legs"(16), and a view of her own body; "I tripped and fell and cut my finger to the bone. I sat up and looked in, to my own body; there was no blood for a moment and I could see, it really was to the bone because there was the bone, not far down at all, shining up at me, white as an eyeball"(16).

The second part of Murder in the Dark builds on the "raw materials" already presented in the first section - smells, blind eyes, feet, seams, recollections, colours etc. - while reintroducing the role of fiction and the potential for uncertainty. "Why do we travel? In other words, what are we doing here?" (19) is the opening question. The answer has to do with the quest for the "real experience... which means mescal with an authentic worm in the bottle, Still, you never know who you can trust. The worm could be faked"(19). In "Raw Materials" again, mundane scenes are presented: the meeting of a stranger in a foreign land, the confrontation with a quaint beggar in a café, predictable outings to visit temples, ancient thrones, water gods and so forth. Again, each scene is unsettled and unsettling: there is the stranger's perverse occupation and activities, the awkwardness of a pushy beggar, the sweat, smell, panic and fear in penetrating the darkness of the pyramid and more useless eyes -blind fish(25) following on blind crocodiles(11). One by one, the writer/murderer/liar exposes fake "real experiences": "We walk back down the corridor... knowing that we have... blundered upon a... profoundly believed game and... spoiled everything"'(25).

Continuing in sections three and four, the reality-deconstruction-fiction -creation structure is applied to explode patriarchal settings as well as to 
illustrate the constraints of language. In "Simmering", a tongue-in-cheek, role-reversal (hi)story turns nasty when aggressive male cooks take to amputating women's tongue to disallow them access to the culinary and eating experience:

This is history. But it is not a history familiar to many people. It exists only in the few archival collections that have not yet been destroyed, and in manuscripts like this one, passed from woman to woman, usually at night, copied out by hand or memorized. It is subversive of me even to write these words. $(32-33)$

"Simmering" points to problems experienced by women writing in patriarchal contexts while "Women's Novels" delineates further difficulties (linguistic in nature - "Last time we looked, monosyllables were male, still dominant but sinking fast" - 34 ) as well as the difference between writing by men and writing by women, in so doing unsettling (patriarchal) reality in which blindness and erupting smells are ever present (34-36). In "Happy Endings", a reductio ad absurdem leads unsettingly to confrontation with death as well as to exposure of traditional fictional devices, such as plot, which is presented as just "one thing after another, a what and a what and a what" (40). The act and tools of writing are further examined in "The Page" and "Mute". In the former, an apparently innocent, blank, white page is transformed into an object of terror as it becomes a skin that can "feel you touching it" (45). The page is touched only at one's peril and then "[ $d]$ arkness wells through" (45). "Mute" ironically links absence of speech and communication with language, thereby undermining language as it is commonly used. Nouns, verbs, vowels appear as useless objects:

Another clutch of nouns, a fistful: look how they pick them over, the shoppers for words, pinching here and there to see if they're bruised yet. Verbs are no better, they wind them up, let them go, scrabbling over the table, wind them up again too tight, and the spring breaks.(49)

Language is a "bad smell" associated with rotted mouths and one is confronted with the problem of how to "wash a language" clean(49). The struggle is for the word that will finally be right, "a compound, the generation of life, mud and light" (49). In "Hopeless", this particular effort is 
presented as being possible only in the future tense. Writer and reader are to arm themselves with words: "this armful of words, together, with"(57).

Alongside this probing at the edges of language is the critical examination of patriarchy and the introduction of the politic in a feminist perspective, particularly in such texts as "Liking Men", "Him" and "Iconography". In "Liking Men", the innocence of the ever-present feet, "pinkly toed and innocuous" (53), is transformed first into the symbolic terror and power of marching, booted feet and then into a rape scene:

\begin{abstract}
Now you see rows of them, marching, marching; yours is the street-level view, because you are lying down. Power is the power to smash, two hold your legs, two your arms, the fifth shoves a pointed intrument into you; a bayonet, the neck of a broken bottle, and it's not even wartime, this is a park, with a children's playground, tiny red and yellow horses, it's daytime, men and women stare at you out of their closed car windows. Later the policeman will ask you what you did to provoke this. Boots were not such a bright idea after all.

But just because all rapists are men it doesn't follow that all men are rapists, you tell yourself.(54).
\end{abstract}

Fear and terror are also illustrated in "Him"; "How many times," the question is asked, "have you awakened in the moonlight and seen those indigo shadows instead of eyes, hard as if cast by granite, and thought, I'm in bed with a killer?" (56). Finally, in "Iconography", the power conferred on men to the disadvantage of women surfaces in domestic lovemaking scenes as in language.

To have her in a position she didn't like, that was power... The greatest power of all is when she doesn't really like it but she's supposed to like it, so she has to pretend... The most important thing is making her. Over, from nothing, new. From scratch, the way he wants... It can never be known whether she likes it or not By this time she doesn't know herself. All you can see is the skin... hard to tell, and she never will, she can't. They don't get into it unless they like it, he says. He has the last word. He has the word.(52)

3. Italics in the original text. 
In all of these fictions - autobiography, parable, romance, horror story, manuscript - Atwood poses writing/fiction as a project in which the writer is a murderer and a liar destroying comfortable patriarchal reality and language, unsettling the reader and using imagination and fiction to transform "reality" into "something else". How does one move to that something/somewhere else? How does one get there? Simply enough, one moves there on one's feet. In "Fainting", the end result of an everyday outing was the production of a new view - a view from the feet, a potential seen/scene from one's own body. In "Hand", "your body lies on the floor, with or without you. Your eyes are closed"(59). In the "windowless corridors we know so well", where "feet in their narrowing shoes hit cement, a thud and then another" (59), the body becomes a hand, the hand of a blind person, as if the only way to glimpse a new reality is by becoming blind to a false or misrepresented one. But in this place with no eyes, one has feet that "learn quietly; they are wiser than the eyes, they are hard to fool..." (59). The body becomes unfooled feet that are hard to trick when walking in the dark, and then it takes a journey into its own flesh: "This is the journey of the body, its hesitant footsteps as it walks back into its own flesh. I close my own eyes so I can see better where we are going"'(59). Eyes are closed but "the third eye, the eye of the body, is opening"'(59) and as it does, Murder in the Dark comes to a close with "Instructions for the Third Eye". In this as in previous texts, vision is not to be trusted and again "language is not always dependable either" (61). Hence, the importance of the third eye, even though it may reveal some of the worst scenery: "the gassed and scorched corpses at the cave-mouth, the gutted babies, the spoor left by generals, and, closer to home, the hearts gone bubonic with jealousy and greed, glinting through the vests and sweaters of anyone at all"'(62). But these things are, and someone has to see them, so the third eye should not be resisted:

... it knows what it's doing. Leave it alone and it will show you that this truth is not the only truth. One day you will wake up and everything, the stones by the driveway, the brick houses, each brick, each leaf of each tree, your own body, will be glowing from within, lit up, so bright you can hardly look. You will reach out in any direction and you will touch the light itself.

After that there are no more instructions because there is no more choice. You see. You see.(62)

From the "I" of the first texts, playing games involving lies, darkness and death to the "eye" of the last texts, bringing light and truth, Atwood presents a challenge to a reality which is misrepresented and miscommunicated. In this, neither language nor vision are dependable. Indeed, as in 
the game called Murder in the Dark, one is to use other senses and move along other seams as a way of undermining phony or fake reality. The sense of smell, for instance, is privileged. Whether the sme!l of the carcass of a half-eaten deer in "Autobiography", the smell of dried rot and smoked eel in "Boys' Own Annual 1911," the damp smell of blurred boyfriends in "Boyfriends," the smell of fear and panic in "Raw Materials," the zoo smells of animals in "Women's Novels," the stink of corpses in "Bread," the rotting smell of words in "Mute," the smell of wet socks and feet in "Worship", smell provides one means of breaking through at its seams a reality (re) presented as real, as truth, but exposed as misrepresentation. Similarly, down-to-earth feet are posed as having a significant role. Whether the view from the feet in "Fainting", the illustration of the power and terror of patriarchal reality via booted feet in "Liking Men", or the feet that are hard to fool in the dark in "Hand", feet move vision from "reality" through a dismantling by fiction towards a new reality. These are means of deconstruction, a deconstruction in which the body and language figure critically in the overall strategy.

In all of this, Murder in the Dark participates in a distinct departure from traditional fiction and fictional traditions in English Canada. In terms of modernist and feminist literary efforts to explore (patriarchal) reality and fiction, the tools and strategies presented in this collection of short fictions and prose poems are perhaps somewhat clumsy. But in their concreteness, the senses of touch and smell, the feet and the body nonetheless effect the deconstruction of misrepresentation - of reality and of language - and lead to the inscription of the (female) body and language in the construction of new forms and fictions. 